\title{
Advances in safe food production of animal and aquatic origin
}

\author{
A. R. Veluru ${ }^{1 *}$ and V. Chandrasekar ${ }^{2}$ \\ ${ }^{1}$ Faculty of Food Science, College of Food and Dairy Technology, Chennai - 600 052, Tamil Nadu, \\ India; ${ }^{2}$ Department of Livestock Products Technology (Meat Science), Madras Veterinary College, \\ Chennai- 600 007, Tamil Nadu, India
}

\begin{abstract}
Major challenges of meat safety comprise the need to control existing and emerging pathogenic microorganisms or antibiotic resistance, additives and chemical residues and traceability issues. Technological advances in processing should focus on providing continuous supply of safe and wholesome food for consumers. Stakeholders like food producers, distributors, handlers bear prime responsibilities and it is also equally important for the consumers to be health conscious. Prevention of food borne illnesses involves rapid and accurate detection of pathogens both at laboratory and field. Rapid and sensitive diagnostics and technology such as Polymerase Chain Reaction and Nuclear Magnetic Resonance detects multiple target microbial pathogens' DNA or proteins. Prevention and control of zoonotic diseases by the animal health and regulatory public health agencies, establishment of food safety objectives with implementation of hazard analysis and critical control points in the processing chain, food handler training and consumer education are equally important issues on food safety. Government must take steps to implement food laws to guard people and their health. There should have collaboration within different stakeholders for benefits of present and future generation.
\end{abstract}

Key words: Animal source foods, Food safety, Food sustainability, Microbial safety

\section{Highlights:}

- A safe, nutritious, equitable and profitable food system is required to obtain food security.

- Animal-source foods are the best sources of high-quality nutrient-rich food to meet the global food security.

- Traceability, animal health, hygienic slaughter and processing, storage and distribution of animal/ aquatic source foods are measures to achieve food safety.

- Personal and processing hygiene are required to achieve microbial, chemical and environmental safety

- A close collaboration of all the stakeholders is necessary to achieve global food safety.

\section{Introduction}

Food is indispensible for life on earth. Food animals includes pigs, cattle, buffaloes, sheep, goats, and poultry, and in aquaculture, fish, crustaceans, and mollusks. Camels, horses, rabbits, guinea pigs, and bees are regionally kept for production of food. Animals reared for food production are important sources of food yielding meat, milk, and eggs. Animal-source foods are the best available sources of highquality nutrient-rich food, particularly for children aged 6-23 months (WHO, 2014). The global food security are driven by forces like increased population growth, urbanization and industrialization; availability of cultivable lands and water resources; climatic changes; animal human interface and food availability, accessibility and loss. Food-producing animals are the major reservoirs of food-borne pathogens (Heredia and Garcia, 2018) leading to food borne illnesses. Food is often exposed to varied contaminants of chemical and microbial origin, subjected to personal and environmental hygiene. There is a record of food borne pathogens related outbreaks during 1980 to 2016 were mainly of Staphylococcus aureus, Vibrio sp.,

"Corresponding Author, E mail: varao1966@yahoo.com 
Salmonella sp., E. coli, Yersinia enteroclitica and Norwalk-like virus in India. Aggregate analysis of Integrated Disease Surveillance Programme data shows food-borne outbreaks together with acute diarrhoeal diseases constitute nearly half of all reported outbreaks under IDSP for the period 2011-2016 (CD Alert, 2017). In recent years, such foodborne disease outbreaks have brought meat safety and associated issues at the forefront of societal concerns. Food safety is important to protect the nation from disease and economic burden. Safe food saves life of individual as well as the whole population. The challenge in food safety gains importance due increase in the rate of risk for infection during livestock management and risk of contamination during product processing and distribution; and increased consumer awareness on hygiene, health and safety. The objective of this paper is to emphasize the importance of animal source foods, provide insight information on the major current and future meat safety challenges and measures to achieve food safety from farm to fork.

\section{Global food security}

The demand of animal proteins is going to be double by 2050 with increment of world population. It is estimated that by 2050 , the human population would be 9-10 billion. FAO has also calculated that there will be huge increment of meat, fish and egg consumption during this period and it is about $73 \%$. Besides there will be enhancement of global demand of cattle meat by $95 \%$ (Ranganathan et al., 2016). Livestock and animal/aquatic source foods (ASF) are vital to food security and sustainability, improving livelihoods, income growth, gender equality, nutrition and health (Adesogan et al., 2019). With rising income, the diet pattern is likely to change where urban populations typically consume higher levels of animal products especially processed meat products (Kearney, 2010). Developments in food safety will influence the food sector to achieve the food security but overcoming of these challenges is not only the role of large food sector as it is much greater for developing economies and all the players are critical in the global food supply (King et al., 2017). Thus, efforts to achieve sustainable development must include a more nuanced understanding of livestock and consider their important implications on the lives of the poor.

\section{Animal source foods and its impact on human health}

Animal-source foods (ASF) supply multiple bioavailable nutrients that are lacking in the cereal-based diets. ASF yields greater quantities of higher quality protein and more bioavailable vitamin A, vitamin D3, iron, iodine, zinc, calcium, folic acid and essential fatty acids compared to other foods. Absorption of iron is greater on consumption of ASF which also increases the absorption of iron from other food sources due to the presence of an iron factor (Navas Carretero et al., 2008). In addition, ASF serves to be the only natural source of vitamin $\mathrm{B}_{12}$, the deficiency of which is associated with anaemia, developmental disorders, lower motor development and poorer cognitive function (Stabler and Allen, 2004). ASF is considered to be vital to meet the global target of the WHO comprehensive implementation plan on maternal, infant, and young child nutrition, which calls for a $40 \%$ reduction in the number of stunted children below 5 yrs by the year 2025 (WHO, 2014). Sustainability must consider nutritionally vulnerable populations, women, and children, and the impact of its low consumption on their lives.

Sustainable development goals: United Nations designed seventeen ambitious sustainable development goals (SDGs) to transform the world food sustainable by 2030 (Smith, 2017). Livestock is one of the major tools for sustainable development of poor people all over the word and it provides protein and often more important than crop production (Mottet et al., 2017). With urbanization and increase in education levels, global demand for ASF is expected to increase in future (Zhang et al., 2017) by $70 \%$ by 2050 (FAO, 2019). Increase 
in ASF consumption is frequently associated with potential risk of acute and chronic diseases. Another risk involves antimicrobial-resistant pathogens which are commonly found in animals, agro-food environments and animal food products (Schwarz et al., 2018) and hence poses risk to animal and human health. These risks highlight the need for improved management practices mitigate disease risks from livestock and their products. Thus, while efforts are made to increase consumption of ASF among the poorest, it becomes equally important to focus on the moderation in ASF consumption and adherence to recommended daily intakes (USHHS and USDA, 2015).

\section{Food safety}

Consumers demand quality and safety of food for the value of money paid. Billions of people are at risk, millions of people become sick, thousands of people die due to consumption of unsafe foods contaminated with pathogens, microbial and chemical contaminants or antibiotic residues (Fung et al., 2018). Children are the most at risk of associated death and serious lifelong health complications from food borne diseases. This could be due to their lack of cognitive ability to understand the food safety risk and their immunity status that makes them succumb to infection even at a low dose (Fung et al., 2018). Foot prints of animal food contaminated with industrial pollutants have also been documented in the past and the marking incident is the Minamata disease due to methyl mercury poisoning through fishes and shell fishes in 1956 and 1965 in Japan leading to cerebellar ataxia, sensory, visual, hearing and speech disturbance (Shimohata et al., 2015). Major challenges in food safety include microbial, chemical and environmental safety which could be achieved through personal and processing hygiene.

\section{Challenges of food safety}

Food products may become contaminated at different stages along the food chain (Hemalata and Virupakshaiah, 2016) which could be during production, processing, distribution, preparation, and/or final consumption (Fig. 1). Different animal products
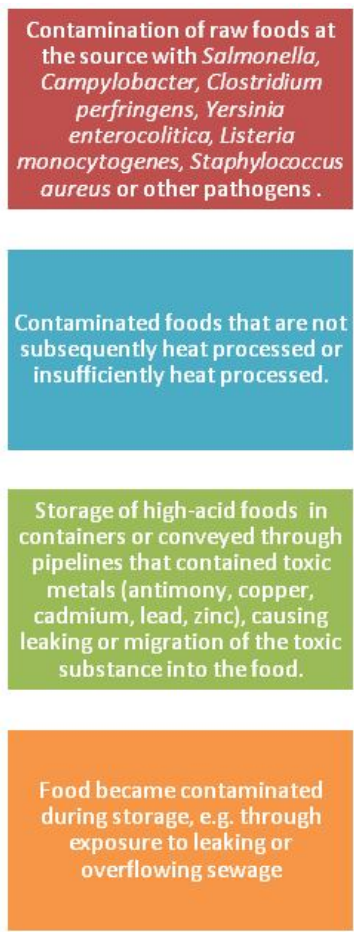
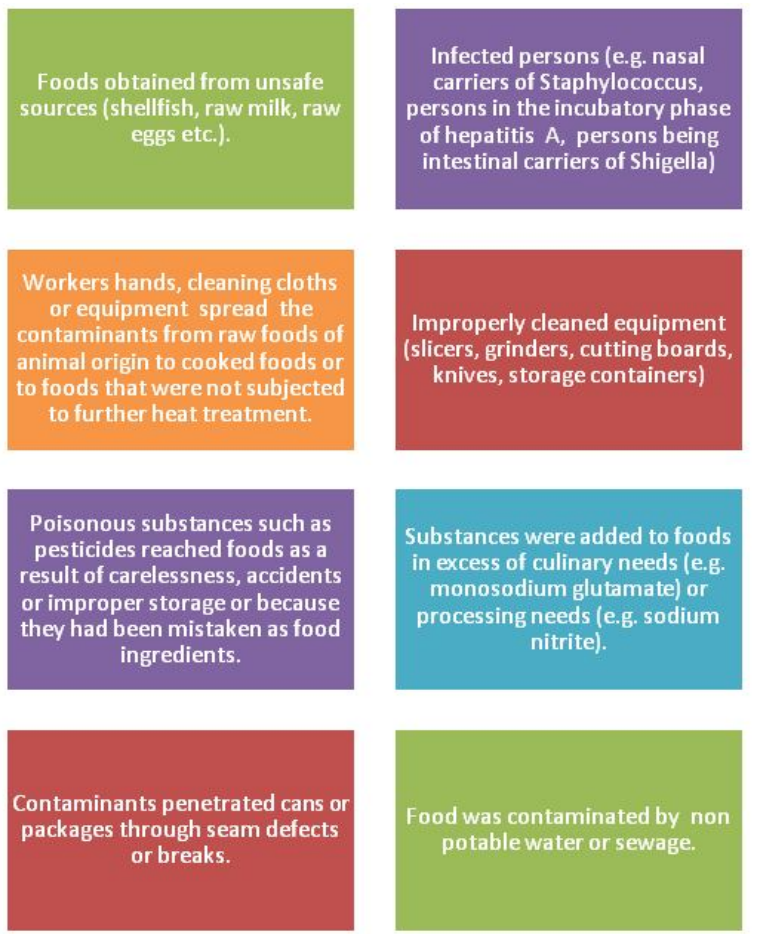

Fig. 1. Sources of contamination in the food supply chain 
considered to be high risk from the point of view of pathogen, toxins, contaminants, adulterants etc owing to its nutritional content, possible processing hazards and other conducing environment that inherently possess within the animal products (Haileselassie et al., 2013; Abebe et al., 2014; Aklilu et al., 2015). Major challenges of food safety are microbial, chemical and environmental in origin.

Microbial safety: Micro organisms in ASF are the potential source of meat borne illness. Of the sources, bacteria are most common causative leading to food spoilage and its consequences ranges from gastroenteritis, hepatic, renal and neurologic syndromes and even death in humans. A total of 2,688 foodborne (Bisht et al., 2021) outbreaks were reported in India between 2009 and 2018.
During this ten-year period, 153,745 food borne illnesses, and 572 deaths were reported to Integrated Disease Surveillance Programme (IDSP) with the majority of deaths in 2012 accounting for $19 \%$ of all reported deaths. Food products of animal origin are considered as major vehicles of food-borne infections (Table 1). Of the outbreaks reported, animal source foods have attributed to be a minimal causative of food borne illness (16\% dairy; $5 \%$ fish and shell fish and $9 \%$ poultry and meat) and chemically contaminated food caused maximal $(70 \%)$ deaths (Fig. 2). Animal health pandemics cause tremendous economic losses to local, domestic or international markets. Animal health pandemics has been reported due to causatives like avian influenza (AI) and foot and mouth disease (FMD) viruses (Grubman and Baxt, 2004; Whitley and Monto, 2006), of which

Table 1. Animal/Marine source foods as vehicle for food borne outbreak in India

\begin{tabular}{llc}
\hline $\begin{array}{l}\text { Animal/Marine } \\
\text { source foods }\end{array}$ & \multicolumn{1}{c}{ Food products } & $\begin{array}{c}\text { No. of } \\
\text { outbreaks }\end{array}$ \\
\hline Fish and Shell fish & Raw fish, Fish curry, Boiled crabs & 25 \\
\hline Dairy & Milk and its products, Curd, Butter, Milk, Kulfi, Ice Cream & 65 \\
\hline Meat-Poultry and Egg & $\begin{array}{l}\text { Chicken curry, Pulav (beef), Chicken biriyani, Toddy (pork), } \\
\text { Chicken and mutton curry, Egg curry, Boiled eggs }\end{array}$ & 58 \\
\hline
\end{tabular}

Reference: https://idsp.nic.in/ (2009-2018)

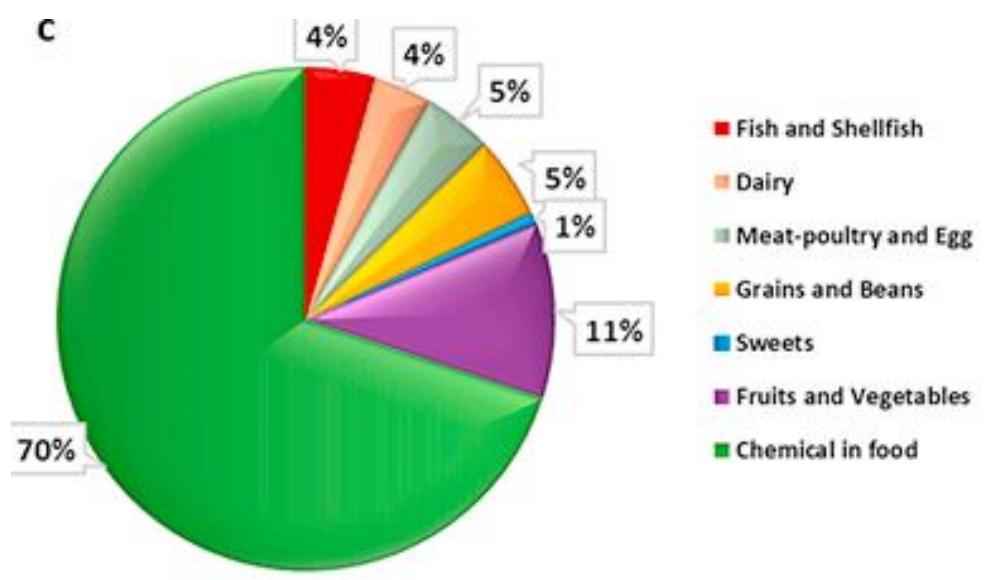

Source: Data for the period from 2009-2018 collected from IDSP website: https://idsp.nic.in/ Adapted from Bisht et al., 2021

Fig. 2. Percentage distribution of small and large outbreaks associated with different food categories during 2009-2018 in India 
H5N1, a high pathogenic strain of Avian Influenza has been identified to cause major death in poultry (Thomas and Noppenberger, 2007). Even though the H5N1 virus may be present in poultry blood and meat, it is not of concern to meat safety because it is inactivated by proper $\left(\geq 70^{\circ} \mathrm{C}\right)$ cooking, and because the oral route of transmission is less important than the non-food borne route (Doyle and Erickson, 2006; Swayne, 2006). Other potentially important pathogens may be Mycobacterium avium sub sp. Para tuberculosis, Escherichia albertii and Clostridium difficile (Oliver et al., 2005).

A variety of contagious bacterial diseases cause suffering and illnesses in animals and brings about economic losses in food production (Duff and Galyean, 2007; Hogeveen et al., 2011; Page and Gautier, 2012; Vaarten, 2012). Respiratory and enteric diseases are among the most important illness in several species, and mastitis is common among milch animals (Page and Gautier, 2012). Bacterial diseases are important also in aquaculture where fish and shrimps are raised in large numbers in close proximity (Oliva, 2012). Pathogenic and spoilage microorganisms as well as antibiotic resistant bacteria and antibiotic resistant genes can gain entry into the food chain at both pre and post harvest stages (Fig. 3). Regardless of the source and route of contamination, micro organisms on entry into the food, have the potential to proliferate to high levels during transportation, storage and handling, particularly under temperature abuse conditions.

Anti-microbial resistance has become a concern of global public health threat owing to the presence of drug residues in the edible tissues of the treated animal as well as an environment pollution (Capita and AlonsoCalleja, 2013; He et al., 2020). Bacterial pathogens of animal and human origin are becoming increasingly resistant to frequently used antimicrobials, including cephalosporins, aminoglycosides and fluoroquinolones. Anti microbial resistant pathogens of human health significance are listed in Table 2. The food safety author of Europe has remarked that bacteria often used for feed preparation might induce risk to animal and human health because it may carry acquired genes of resistance (EFSA, 2007). The extra-chromosomal genes impart resistance to an entire antimicrobial class. A number of these resistance genes have been associated with large, transferable, extra chromosomal DNA elements, called plasmids. Other DNA mobile elements, such as

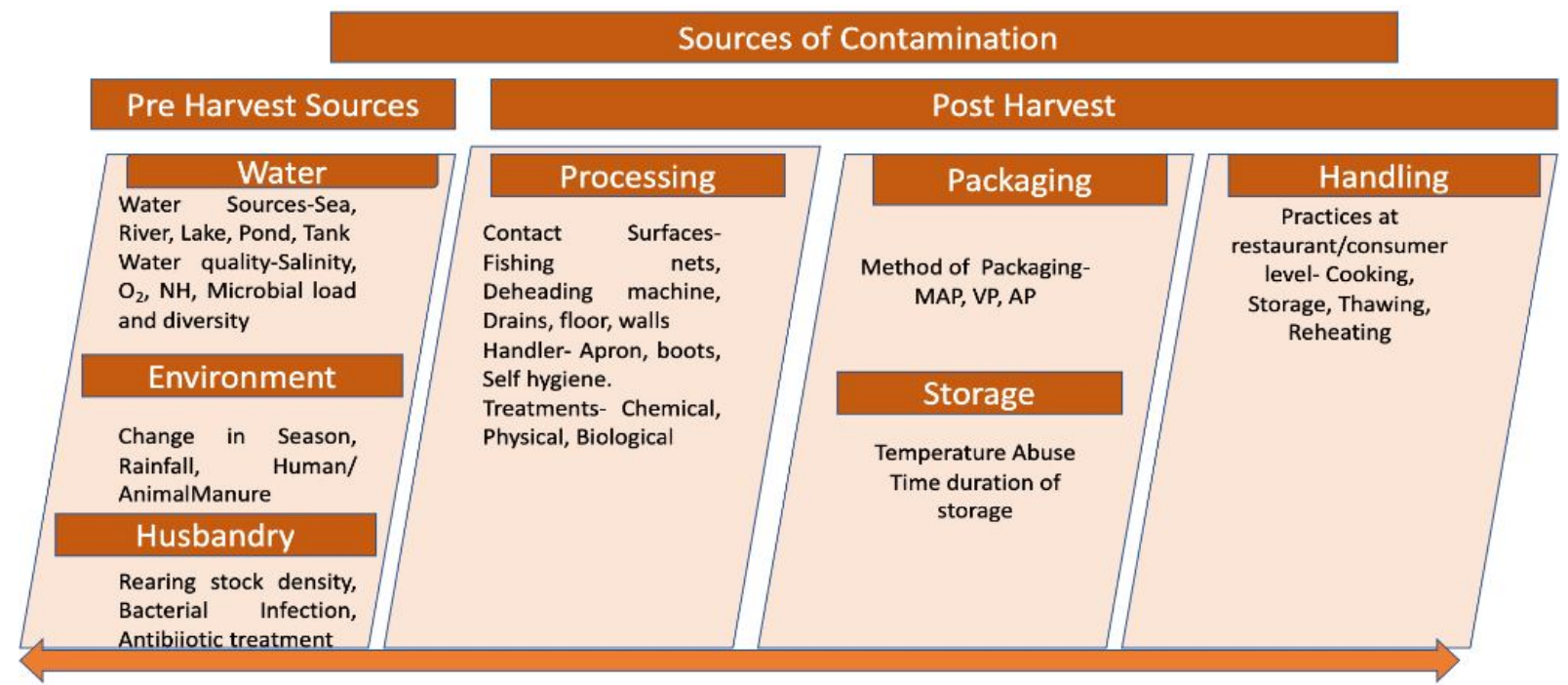

Fig 3. Sources of entry of micro-organisms, antibiotic resistant bacteria and antibiotic resistant genes into fish and fish products 
Table 2. Antimicrobial resistant pathogens of human health significance

\begin{tabular}{|c|c|}
\hline Microbe & Antimicrobial resistance \\
\hline Enterobacteriaceae & $\begin{array}{l}\text { Aminoglycoside, } \beta \text {-lactams, fluoroquinolone, chloramphenicol, } \\
\text { trimethoprim }\end{array}$ \\
\hline Enterococcus & Aminoglycoside, $\beta$-lactam, erythromycin, glycopeptide \\
\hline Haemophilus influenza & $\beta$-lactams, tetracycline, chloramphenicol, trimethoprim \\
\hline Mycobacterium tuberculosis & Aminoglycoside, ethambutol, isoniazid, rifampim \\
\hline Neisseria gonorrhoeae & $\beta$-lactam, tetracycline, fluoroquinolone \\
\hline Pseudomonas aeruginosa & $\begin{array}{l}\text { Aminoglycoside, } \beta \text {-lactams, tetracycline, sulfonamide, } \\
\text { fluoroquinolone }\end{array}$ \\
\hline Shigella dysenteriae & Ampicillin, chloramphenicol, tetracycline, trimethoprim-sulfonamide \\
\hline Staphylococcus aureus & $\begin{array}{l}\text { Chloramphenicol, macrolide, trimethoprim, fluoroquinolone, } \\
\beta \text {-lactam, tetracycline }\end{array}$ \\
\hline Streptococcus pneumoniae & Aminoglycoside, chloramphenicol, macrolide, penicillin \\
\hline
\end{tabular}

Source: McDermott et al., 2002

transposons and integrons may account for the rapid dissemination of resistance genes among different bacteria (McDermott et al., 2002).

Throughout the world, use of antimicrobial agents in animal husbandry and aquaculture has increased to an extent of 63,151 tons in 2010 , and estimated to increase by $67 \%$ in 2030 in developed and developing country particularly (Van Boeckel et al., 2015). Therefore, throughout the globe, antibiotic resistance bacteria become a challenge for the food industry as a whole (Capita and Alonso-Calleja, 2013; Preena et al., 2020). The residual effect of antibiotics to public health is becoming an increasing concern; therefore, scientists should be concerned for its prudent and judicious use, which has been reviewed by Okocha et al. (2018).

Increasing food handlers' knowledge and awareness of food safety practices is essential to make handling safer and improve the safety of animal/aquatic source products. Many novel intervention strategies have been proposed and tested for the control of different microorganisms on fish and fish products (Sheng and Wang, 2020). Most of the novel processing methods is non thermal, to retain the nutrition value and sensory attributes of fish. Olatunde and Benjakul (2018) reviewed the non thermal processes including physical processing technologies such as pulsed electric field, high hydrostatic pressure, cold plasma, ultraviolet and irradiation and chemical pretreatments such as acidic electrolyte water and ozone washing. A combination of different interventions (also known as hurdle technology) has been widely studied to achieve a better preservation and to ensure fish and fish products safety. Chen et al. (2020) reported that a combination of $6 \%$ salt and vacuum packaging extended the shelf life of Russian sturgeon during storage at $4^{\circ} \mathrm{C}$ by delaying the growth of Pseudomonas. Sorensen et al. (2020) examined the combination of super-chilling and MAP on the microbial quality of Atlantic cod and reported extension of 32 days storage life on superchilling at $-1.7^{\circ} \mathrm{C}$ and MAP storage with $40 \% \mathrm{CO}_{2}$ and $60 \% \mathrm{~N}_{2}$ compared to the regular air storage on ice for 15 days. Decontamination methods thus proposed and applied to get rid of situation of microbial load in fish and fish products through various methods of interventions like physical, biological and chemicals (Sternisa et al., 2016; da Cunha et al., 2018; Ringo et al., 2018; Kuebutornye et al., 2020; Kumar et al., 2020). Advancements in these areas, includes photodynamic inactivation of bacteria and the 
identification of new natural antimicrobials which warrant further investigation to ensure fish and fish product safety.

Chemical safety: Chemical additives, such as artificial colorants, synthetic preservatives, heavy metals and pesticide residues have been reported in animal source foods. Inadequate hygiene, industrial proximity and leaching from processing utensils have been the source of heavy metal and pesticide contamination. Improper processing/cooking methods have become the potential source of carcinogenic compounds like heterocyclic amines and polycyclic hydrocarbons in processed meats.

Environmental safety: Improper sanitary conditions during processing and unhygienic conditions during transportation and distribution lead to contamination of food. Improper storage and disposal and inadequate recycling of by-products lead to waste accumulation, attracting pests and insects leading to environmental pollution. Handling of manure of animals, as well as the direct animal-to-human transmission of pathogens through environment, water and food contamination, will have to be taken seriously under consideration by food producers, public health regulators and consumers.

\section{Food borne illnesses/intoxications from animal and aquatic sources}

Globalization of trade has made the food to become a major pathway for human exposure to pathogenic microbial, to enter at many points along the value chain, causing food borne illness.

The reasons for foodborne illness have been categorized as poor handling with in-sanitation practices often due to lack of education of the food handlers in developing countries and it became one of the major food borne diseases (Ayana et al., 2015; Abunna et al., 2016). This has been supported with the observation of WHO where they have categorized that $30 \%$ population suffers from food-borne diseases in developing countries and up to 2 million deaths were estimated per year (Abunna et al., 2016). Often such diseases are of zoonotic in nature, transmitted through different means of contacts (Chlebicz and Slizewska, 2018). Kadariya et al. (2014) has remarked that such diseases often becoming infectious and toxic in nature where food or water is the chief vehicle for the transmission. In another study Dhama et al. (2013) and Addis and Sisay (2015) had categorized all these diseases under three groups of foodborne illness.

Food-borne pathogens including bacteria, viruses, fungi and parasites (Zhao et al., 2014) are the primary cause of food spoilage and food borne diseases (Hemalata and Virupakshaiah, 2016). Food-borne microbes affects food safety and cause human infections after consumption of the animal products contaminated with microorganisms or their toxins (Heredia and Garcia, 2018). Common food borne hazards, and the associated morbidity, mortality and health burden are summarized in Table 3 . Nowadays, the awareness has been growing on the public health impact of zoonotic food-borne pathogens transmitted from animal-originated food (Bantawa et al., 2018). Abebe et al. (2020) reviewed the common bacterial food borne pathogens of zoonotic importance in Ethiopia. Although 31 pathogens have been identified as causatives of food-borne diseases (Zhao et al., 2014), bacterial pathogens including Staphylococcus aureus, Salmonella species, Campylobacter species, Listeria monocytogenes and Escherichia coli are the common causes of food-borne diseases and death in the world (Zhao et al., 2014; Hemalata and Virupakshaiya, 2016; Assefa and Bihon, 2018; Bantawa et al., 2018; Elmonir et al., 2018).

Different means of emerging pathogens by developing changes of the character of the pathogens with association of new food vehicles, multidrug resistant pathogens are becoming more concerned to human health with different unknown immerging problem than susceptible bacteria (Akbar and Kumar-Anal, 2011; Hemalata and Virupakshaiya, 2016; 
Safety of animal and aquatic foods

Table 3. Common food borne hazards and its morbidity, mortality and disability burden

\begin{tabular}{llccc}
\hline Hazard & \multicolumn{1}{c}{ Infectious/toxic agent } & $\begin{array}{c}\text { Incidence of } \\
\text { foodborne illness }\end{array}$ & $\begin{array}{c}\text { Death due to } \\
\text { foodborne illness }\end{array}$ & $\begin{array}{c}\text { Total disability } \\
\text { adjusted life } \\
\text { years }\end{array}$ \\
\hline Bacteria & $\begin{array}{l}\text { Salmonella, Vibrio, E. coli, } \\
\text { Shigella, Listeria, Brucella, } \\
\text { Campylobacter }\end{array}$ & $359,747,420$ & 272,554 & $20,188,792$ \\
\hline Virus & Noro virus, Hepatitis A & $138,513,782$ & 120,814 & $3,849,845$ \\
\hline Protozoa & $\begin{array}{l}\text { Entamoeba, Giardia, } \\
\text { Cryptococcus, Toxoplasma }\end{array}$ & $77,462,734$ & 6,242 & $1,311,435$ \\
\hline Worms & $\begin{array}{l}\text { Cestodes, Nematodes, } \\
\text { Trematodes, Helminths }\end{array}$ & $26,063,664$ & 90,261 & $11,599,735$ \\
\hline Chemicals & $\begin{array}{l}\text { Aflatoxins, Cyanogen, } \\
\text { Dioxin, Heavy metals }\end{array}$ & 217,632 & 19,712 & 908,356 \\
\hline
\end{tabular}

Source: Compiled from WHO (2015)

Tsepo et al., 2016). Commonly encountered microbial pathogens and toxins include the following categories.

Bacteria: Bacterial pathogens of concern that need to be controlled in fresh meat include Salmonella, Campylobacter, Enterohaemorrhagic E. coli including serotype $\mathrm{O} 157: \mathrm{H} 7$, as well as other enteric pathogens. Fever, headache, nausea, vomiting, abdominal pain and diarrhea are the symptoms associated with enteric pathogens. Sources of Salmonellosis include eggs, poultry and other products of animal origin. Listeria monocytogenes is also considered important in readyto-eat meat, poultry products and unpasteurized dairy products due to its ubiquitous presence and potential contaminants during processing even its ability to growth under refrigerated condition (Tompkin, 2002; FDA/FSIS, 2003). Listeria infection increases the risk of spontaneous abortions and stillbirths.

Virus: Norovirus infections are characterized by nausea, explosive vomiting, watery diarrhea and abdominal pain. Hepatitis A virus spreads typically through raw or undercooked seafood or contaminated raw produce and through infected food handlers.

Protozoa: Cryptosporidium, Entamoeba histolytica or Giardia, enter the food chain via water or soil and can contaminate fresh produce and cause gastro-intestinal disturbances.

Worms: Improper processing and sanitation, inadequate storage and hygiene, invites the worms of cestodes, nematodes, trematodes and helminthes, which though not as fatal as bacteria and virus, accounts for food borne disability burden. Fish-borne trematodes are transmitted only through food. Echinococcus spp. may infect people through food or direct contact with animals.

Chemicals: Chemical contaminants include naturally occurring toxins like mycotoxins, marine biotoxins and cyanogenic glycosides; chemical residues of pesticide/wormicide; environmental pollutants like heavy metals, dioxins and polychlorinated biphenyls (PCBs) from improper disposal of industrial waste and carcinogenic compounds like heterocyclic amines, polycyclic hydrocarbons from improper cooking methods. Environmental pollutants gains access through air, water and soil and accumulate in animal food chains. Dioxins are highly toxic and can cause reproductive and developmental problems, damage the immune system, interfere with hormones and cause cancer. Finally, heavy 
metals such as lead, cadmium and mercury can cause neurological and kidney damage.

\section{Measures of food safety from farm to fork Animal and food traceability: Animal} traceability as well as food product recalls are major issues of worldwide interest and may have major food safety implications (Felmer, 2006). The spread of BSE across the world has created the necessity of animal identification and traceability. Selection of precision requirements and appropriate technology; maintenance of confidentiality and payment of costs are the major issues to be considered in the process of establishment of animal identification and tracking systems. It should include premises number and animal identification number, and also cover the feed, livestock and meat (Sofos, 2008). Advanced biotechnological tools are used for meat speciation and authentication, including genetic engineering, polymerase chain reaction (PCR), random amplified polymorphic DNA (RAPD), amplified fragment length polymorphism (AFLP), rDNA technology, matrix associated laser desorption ionizationtime of flight mass spectroscopy (MALDI-TOF MS) etc. (Naveena et al., 2017). RFID technologies can be utilized in food supply chains to detect package opening or tampering (Wang et al., 2020), facilitate continuous traceability (Badia-Melis et al., 2018; Fan et al., 2019), and ensure safety of food product, particularly for perishable foods (Wang et al., 2019d; Soltani Firouz et al., 2021). Flexible RFID tag has been applied in the packaging of cured ham (López-Gómez et al., 2014).

Animal health and production: Stress in animal affects meat quality and possibly lead to more contamination and cross-contamination with pathogens on account of higher pathogen shedding. Humane handling of food animals pre slaughter is very crucial to prevent stress and should receive increased attention worldwide (Grandin, 2006). Good animal husbandry practices make the meat and dairy products safer or of better quality.
New challenges like global climatic change, antibiotic resistance microbes/genes urgently call for innovative and efficient solutions, and microbiome therapy is certainly a promising approach. One of the most important strengths of microbiome manipulation is protection of animal populations by the use (or replacement) of natural microbial communities, with minimal secondary impact as is associated with the use of antibiotics. Host associated microbiome protect the host against pathogens and toxic compounds and contributes to their nutrition, growth, development. Studies on microbiome and their omics points to overall contributions of the microbiomes to their hosts and targeting these processes can improve animal fitness and health. Customized combinations of microbialbased therapies help to promote animal health and contribute to the sustainable husbandry (Peixoto et al., 2021).

In India, probiotics are currently used as food additives, dietary supplements and in animal feed (FAO, 2010). The beneficial role of microbiome in food production is to improve the production and yield of meat in cattle (Huws et al., 2018; Sun et al., 2020). Understanding the science of rumen microbiome is of utmost importance because of its relation to animal, human and environment through its direct influence on the nutrition and health of animals, the products and by-products they provide, and the production of greenhouse gases. The direct impact of rumen microbiome on the quality and yield of meat and dairy products and the indirect impact on human health and development are reviewed recently (Huws et al., 2018). de Frietas et al. (2020) and Sun et al. (2020) applied metabolomics, metagenomics, and transcriptomics to evaluate the effect of rumen microbiome on milk production and weight gain respectively. These studies indicate the potential of probiotics to improve meat production and yields in cattle. Microbiome studies of pigs have focused primarily on the organisms present in the gut tract and how they relate to pig health and production. The faecal microbiome composition of pigs are influenced by sex, age, genetics, and management (Wang et al., 2019a; 
Wang et al., 2019b; Maltecca et al., 2020; Quan et al., 2020). Other studies have also associated the resistome in the healthy pig gut with its microbial composition (Joyce et al., 2019) and also indicated it to be highly shared by the pig, human, and mouse resistomes (Wang et al., 2019 c), representing a risk of horizontal transfer of resistance genes. Antibiotics that are used routinely in the poultry industry to inhibit pathogens and increase growth yield have proven to have long-term impacts on the poultry microbiome. Elokil et al. (2020) have demonstrated persistent significant changes in gut microbes following exposure to enrofloxacin and diclazuril which also induce or repress certain microbial pathways.

Microbiome research in fishes involves cataloging the symbionts and pests that cause disease in fish stocks and studies related to market quality and growth. de Bruijn et al. (2018) reviewed the research undertaken to mitigate diseases in fish aquaculture by a more sustainable method, using the introduction of beneficial bacteria, rather than by antibiotics. Talwar et al. (2018) discussed the fish gut microbiome and proposed that research focus on functional microbiomics to improve yields in fish aquaculture. A recent review by Yeh (2020) explored the use of probiotics in food oysters to improve marketability by reducing disease in oysters, increasing yields, reducing bacterial contaminants that would affect humans, and increasing shelf life.

Slaughter of food animals: Intervention during slaughter of food animals includes carcass decontamination for reduction of pathogens. Control of contamination at slaughter includes cleaning of animals and removal of hair before hide removal and the interventions after hide removal includes removal of visible soiled spots in carcass by knife-trimming or steamvacuuming and washing/ spraying/ rinsing of carcasses with cold/warm/hot water or chemical solutions or pressurized steam, followed by chilling of carcasses. These controls may be applied as multiple or combined, sequential or simultaneous interventions (Sofos and Smith,
1998). Sequential application involves cleaning of animal hide, followed or preceded by dehairing by physical/chemical means, hide removal, washing of carcass before evisceration and after attaining "zero tolerance" for visible soil, decontamination, and final carcass chilling. Certain interventions like application of steam and vacuum and warm acid solutions are applied as combined simultaneous treatments (Sofos, 2005).

Processing of animal source foods: Application of biotechnology during processing involves careful monitoring of the production process and cleaning and sanitation to control microbial contamination in the final product (Ochoa et al., 2005). Different processing techniques like physical, physiochemical and biological methods are considered to control pathogens and are called as antimicrobial intervention or control (ILSI, 2005; Koutsoumanis et al., 2006). Physical hurdles include thermal (low and high temperature) or non thermal (e.g., irradiation, high pressure) processes, and packaging treatments (e.g., modified atmospheres, active, intelligent packaging systems). Physicochemical interventions include reducing $\mathrm{pH}$ by applying antimicrobials, reducing water activity by drying, modifying the oxidation/reduction potential (Eh) through packaging. Irradiation, high hydrostatic pressure, electroporation with pulsed electric fields, ultrasonic waves, oscillating magnetic fields, cell lysis with bacteriophages or enzymes, active packaging with antimicrobials and various combinations of such processes (e.g., manothermosonication; irradiation and heat; pressure and heat) are novel processing and preservation technologies applied in meat and meat products. Biological interventions include application of microbial competitors including lactic acid bacteria or their antimicrobial products including bacteriocins such as nisin.

Biotechnological advances in food processing involve the development of tailor made micro organisms for specific use in manufacturing and service industries 
(Okechukwu et al., 2019). Use of commercially available starter cultures has led to the production of fermented fish sauces in Asia (Graham, 1994), Nham, meat from fermented pork (FAO, 2010). Advances in marketing have improved the availability and accessibility of packaged fermented products such as kimchi, miso and tempeh through the supermarkets across Asia (FAO, 2010). Dairy industry in New Zealand has benefited the fruit of biotechnology tools, increasing the amount of the protein casein in milk by 13 percent, which is essential to cheese making (Betsch, 1998).

\section{Storage and distribution of animal source}

foods: After processing, it is crucial to ensure proper storage, handling and distribution to prevent cross-contamination or microbial growth during the latter part of the supply chain. Uninterrupted cold chain during food supply ensures safety as well as reduces food waste. Detection of pathogenic micro organisms through application of sensors and indicators is crucial to the food industry (Chowdhury and Morey, 2020). The applications of responsive packaging in animal and aquatic foods are listed in Table 4. Informative responsive packaging (Intelligent packaging) serves to be a novel technology in providing real time monitoring, extensive communication and warning on the status of food quality through visual signals (Yousefi et al., 2019), and assures safety by reducing the risk of food borne diseases (Zhang et al., 2021). This novel technology serves as an anti-counterfeiting tool to improve brand mark and market recognition (Mohammadian et al., 2020). Utilisation of nanozyme based biosensors helped in assuring food quality and safety by detection of food contaminants like pathogens and toxins (Zhang et al., 2019) and evaluation of toxicity (Ye et al., 2019). Timetemperature indicators (TTI) were developed to record the temperature fluctuations during storage of the food product (Lee et al., 2015). Critical temperature monitoring indicator devices are most suitable for monitoring the quality of foods delivered through the cold chain, such as chilled meat, frozen seafood, and dairy products (Dodero et al., 2021). Enzymatic TTIs, diffusion-based TTIs, and microbial TTIs are widely used in the food industry. Enzymatic TTI response depends on the reaction catalyzed by an enzyme at a certain temperature range (Pandian et al., 2020). Diffusion-based TTIs depends on the diffusion of ink with changes in temperature (Soltani Firouz et al., 2021).

Nevertheless, risk is involved in the application of both types of responsive packaging, specifically in the informative responsive packaging, where false positive or false negative results are likely to be happened leading to food wastage or consumption of spoiled food (Soltani Firouz et al., 2021). There is also likely chance of wrong corrective response to a false stimuli resulting in excess release of active agents or premature loss of packaging functions, leading to migration of unwanted substances from packaging materials which may change the sensory properties of packaged foods or be a threat to consumers' health (Mohammadian et al., 2020). Furthermore, the commercialization of responsive packaging ran into a brick wall, partly due to the lack of specific legislation and uneven consumer acceptance. Thus, more research should be pursued to address these concerns.

Education of food handlers and consumers: Lack of adequate knowledge about food safety during purchase, storage, cooking and handling has led to outbreaks of foodborne illness (McMeekin et al., 1997) which could be avoided by taking intensive efforts to educate foodhandlers and consumers in food safety principles. It is necessary to teach consumers the basics of proper washing/thawing of fresh/frozen animal/aquatic source foods, proper and effective cooking and reheating, adequate separation of uncooked and ready-to-eat foods, and washing of hands, cutting boards, knives, etc. At-risk individuals should be instructed to avoid risky foods and raw or unpasteurized foods.

Testing of livestock and marine products: Rapid and accurate detection of food borne 
Table 4. Responsive packaging application in animal and aquatic source foods

\begin{tabular}{|c|c|c|}
\hline Research & $\begin{array}{l}\text { Animal/Aquatic } \\
\text { source food }\end{array}$ & Reference \\
\hline \multicolumn{3}{|l|}{ Informative (intelligent) responsive packaging } \\
\hline \multicolumn{3}{|l|}{ Time-temperature Indicators } \\
\hline $\begin{array}{l}\text { TTI based on the release of free fatty acids due to } \\
\text { lipid oxidation during temperature abuse in frozen } \\
\text { chicken meat is developed }\end{array}$ & Frozen chicken meat & Jaiswal et al., 2020 \\
\hline $\begin{array}{l}\text { TTI for chilled foods based on glucose oxidase- } \\
\text { redox reaction is developed }\end{array}$ & Frozen pork & $\begin{array}{l}\text { Mijanur Rahman } \\
\text { et al., } 2018\end{array}$ \\
\hline \multicolumn{3}{|l|}{ Gas Sensor } \\
\hline $\begin{array}{l}\text { Colorimetric sensor array technology is used as an } \\
\text { excellent odor-image-based tool for quick and } \\
\text { reliable evaluation of food quality and safety of meat }\end{array}$ & Chicken meat & Chen et al., 2017 \\
\hline \multicolumn{3}{|l|}{ Freshness Indicators } \\
\hline $\begin{array}{l}\text { Methylcellulose/chitosan nanofiber composite films } \\
\text { incorporated with barberry anthocyanins to monitor } \\
\text { the freshness of meat and seafood }\end{array}$ & Meat and Seafood & $\begin{array}{l}\text { Alizadeh-Sani } \\
\text { et al., } 2021\end{array}$ \\
\hline $\begin{array}{l}\text { An anthocyanin-agarose film indicating } \\
\text { the freshness of dairy products }\end{array}$ & Dairy products & Weston et al., 2020 \\
\hline $\begin{array}{l}\text { Intelligent } \mathrm{pH} \text {-sensitive indicator fabricated by } \\
\text { bacterial cellulose film with the incorporation } \\
\text { of anthocyanin for monitoring the freshness } \\
\text { of packaged shrimp }\end{array}$ & Shrimp & $\begin{array}{l}\text { Mohammadalinejhad } \\
\text { et al., } 2020\end{array}$ \\
\hline $\begin{array}{l}\text { A colorimetric } \mathrm{H}_{2} \mathrm{~S} \text { sensor based on gellan gum } \\
\text { hydrogel with silver nanoparticles (AgNPs) to } \\
\text { monitor meat spoilage in real time }\end{array}$ & Meat spoilage & Zhai et al., 2019 \\
\hline $\begin{array}{l}\text { Cellulose-based ratiometric fluorescent material with } \\
\text { sensitive amine-response employed as real-time and } \\
\text { effective indicator for seafood freshness }\end{array}$ & Seafood & Jia et al., 2019 \\
\hline $\begin{array}{l}\text { Red, green, and blue (RGB) digital images of the } \\
\text { three-layered indicator captured by smartphone } \\
\text { for judging the freshness of chicken breast }\end{array}$ & Chicken breast & Lee et al., 2019 \\
\hline \multicolumn{3}{|l|}{ Corrective responsive packaging } \\
\hline $\begin{array}{l}\text { The design of consumer-controlled pH-triggered } \\
\text { release of lysozyme from zein composite films is } \\
\text { applied for the preservation of packed } \\
\text { smoked salmon }\end{array}$ & Salmon fish & $\begin{array}{l}\text { Boyaci and } \\
\text { Yemenicioğlu, } 2018\end{array}$ \\
\hline $\begin{array}{l}\text { Bacterial protease (secreted from Bacillus cereus)- } \\
\text { triggered release of cinnamon essential oil to } \\
\text { extend the shelf life of beef }\end{array}$ & Beef & Lin et al., 2017 \\
\hline
\end{tabular}

pathogens is essential criterion in health surveillance programmes to detect the source of pathogen and enact control interventions through HACCP programs in food chain to assure food safety and control food borne infections. Detection methods of microbials 
have made advances from culture based to rapid and more sensitive antigen based and DNA based diagnostics. Food poisoning causing harmful bacteria such as Listeria and Clostridium botulinum are detected using monoclonal antibody tests, polymerase chain reaction (PCR) methods, and DNA probes (BREI, 2006). Wide arrays of biosensors have been developed by commercial companies to detect allergens, toxins and pathogens (Mustafa and Andreescu, 2018). A microfluidic biosensor based on impedence has enabled rapid and sensitive detection of Salmonella in turkey (Liu et al., 2019). Jin et al. (2020) designed a rapid, nondestructive biosensor to monitor Salmonella in milk. Advances in proteomics and genomics technologies thus have proved to detect the food contaminants and their toxins with more sensitivity and specificity (Pal et al., 2017). These advanced molecular tests are used mainly in the sophisticated laboratories and not readily available at field level for clinical practitioners. Simple instruments can be utilized at field level to detect microbial pathogens and contaminants but it requires higher sample measurement volume to achieve specificity and accuracy of near $100 \%$. Detection of biomarkers will help to save time and overhead expenses, but still the Point of Need Test (PONT) devices for pathogen detection does not exist for many of the pathogens of interest in animal farming and aquaculture.
Commonly utilized rapid polymerase chain reaction (PCR) based technology is real-time PCR (qPCR), which detects microbial upon cell enrichment, DNA amplification within $3.5 \mathrm{hrs}$ but this system is unable to detect multiple bio markers. Nuclear Magnetic Resonance (NMR)nanotechnology platform detects multiple target microbials by hybridizing to DNA or protein of the pathogens and simultaneously runs assays using biomarkers like nucleic acid and antibodies (Yang et al., 2017). Detection of multiple biomarkers for a single microbial in same detection device, provides both specificity and accuracy and hence, could be used as a screening and as well as a confirming tool. It is more sensitive than other systems due to standard amplification process plus signal amplification through nanoparticles. The polymerase chain reaction is applied to amplified DNA and the antibody ligands method can be applied for protein structure amplification. Further specificity could be achieved by multiplexing with large sample volume to analyse multiple biomarkers. Comparison of two molecular techniques for Salmonella is provided (Table 5) to understand their benefits.

\section{Regulations and food safety programmes}

The global harmonization of laws and regulations; and implementation of prerequisite programmes of food safety like good manufacturing/storage/packaging practices are

Table 5. Comparison of two molecular techniques for detection of Salmonella

\begin{tabular}{lll}
\hline $\begin{array}{l}\text { Non-culture based } \\
\text { microbial detection }\end{array}$ & $\begin{array}{c}\text { NMR Nanotech } \\
\text { (microbes, nucleic acids, proteins) }\end{array}$ & $\begin{array}{c}\text { PCR } \\
\text { (Salmonella) }\end{array}$ \\
\hline Detection method & PCR-NMR & Isothermal PCR \\
\hline Sample-to-answer time & $<1 \mathrm{~h}$ & $10-26 \mathrm{~h}$ \\
\hline Sample type & Food, tissue, water, soil, feces & Fish tissue \\
\hline Sample size & $1-325$ g (food); 0.1g (Shrimp tissue) & $25-325 \mathrm{~g}$ \\
\hline $\begin{array}{l}\text { Limits of detection } \\
\text { (LOD) }\end{array}$ & $10^{3}$ colony forming unit $(\mathrm{CFU}) / \mathrm{mL}$ post & $\begin{array}{l}10^{4} \mathrm{CFU} / \mathrm{mL} \text { post } \\
\text { enrichment; } 1 \\
\text { enrichment; 1-10 CFU/analytical unit }\end{array}$ \\
\hline Sensitivity & $>98 \%$ & $98.7 \%$ \\
\hline Specificity & Near $100 \%$ & $98.3 \%$ \\
\hline
\end{tabular}

Source: Ferguson et al., 2017 and Yang et al., 2018

Adapted from Fung et al., 2018 (Commercial testing brand names not mentioned) 
key features to achieve the microbial safety in animal and aquatic food sources. Food Safety Standards Authority of India does regular monitoring and surveillance to assure safety of food products. Periodical monitoring of food assures $95 \%$ detection of microbial or chemical contaminants. Food safety inspector has responsibility to inspect foods during any time of the food supply chain which includes processing, packaging, storage and distribution. Food surveillance helps to investigate and control the movement of potentially contaminated products along and across the nations. In India, programs such as the Food Safety Management Systems (FSMS) ensure safety of current and future food supply. The Pathogen Reduction/ Hazard Analysis and Critical Control Points system must be implemented in any of the food processing unit, so that food safety risks are addressed more adequately.

\section{Conclusion}

Food safety and nutrition are closely associated as unsafe food leads to malnutrition and outbreaks of food-borne disease remains to be a public health concern. Detection of microbes alone should not be relied as the only means to assure product safety (ICMSF, 2002). Efforts should be taken to produce healthy animals and avoid antibiotic usage to reduce the incidence of infectious diseases (Bengtsson and Greko, 2014) and ensure safety of animal and aquaculture products free of antibiotic residues. Use of probiotics, phage therapy, and essential oils are better alternatives to antibiotics in control of antimicrobial residues in food.

\section{REFERENCES}

Abebe E, Gugsa G and Ahmed M, 2020. Review on major food-borne zoonotic bacterial pathogens. J Tropical Med, doi: 10.1155/2020/4674235

Abebe M, Hailelule A, Abrha B, Nigus A, Birhanu M et al., 2014. Antibiogram of Escherichia coli strains isolated from food of bovine origin in selected woredas of tigray, Ethiopia. African J Microbiol Res, 6(3): 17-22, doi: 10.5897/ JBR2014.0126

Abunna F, Abriham T, Gizaw F, Beyene T, Feyisa A
Efforts are still required to harmonize regulations at pre harvest farming practices and postharvest processing, storage and distribution with due importance to control environmental pollution. Government agencies such as Bureau of Indian Standards (BIS) and Food Safety Standards Authority of India (FSSAI) must enforce a fair and equitable law to protect public health and food safety. It is imperative that the health authorities should enact and strengthen the disease surveillance program to avoid pandemic spread as like the existing situation, the whole world faces with regard to COVID 19 crisis. On the whole, a close collaboration between all the stakeholders is necessary to achieve a meaningful food safety for every person in a global perspective. Responsibility needs to be shared among producers, suppliers and consumers in collaboration with the support from governments to ensure food safety in the future (Fung et al., 2018).

Conflict of interest: Authors have no conflict of interest in this study.

Author's contribution: VAR: Conceptualized the idea, critically reviewed and edited the manuscript; VC: Designed the structure and wrote the review.

\section{ACKNOWLEDGEMENT}

The authors express their gratitude to the Tamil Nadu Veterinary and Animal Sciences University, Chennai, Tamil Nadu, India for the opportunity and environment to work with animal source foods and assure food safety.

et al., 2016. Staphylococcus: Isolation, identification and antimicrobial resistance in dairy cattle farms, municipal abattoir and personnel in and around asella, Ethiopia. J Vet Sci Tech, 7(6): 1-7, doi: 10.4172/2157-7579.1000383

Addis M and Sisay D, 2015. A review on major food borne bacterial illnesses. J Trop Dis, 3(4): 1-7, doi: 10.4176/2329-891X.1000176

Adesogan AT, Havelaar AH, McKune SL, Eilitta M and Dahl GE, 2019. Animal Source Foods: 
Sustainability problem or malnutrition and sustainability solution? Perspective matters. Glob Food Secur, 25(4): 100325 doi: 10.1016/j.gfs. 2019.100325

Akbar A and Kumar-Anal KA, 2011. Food safety concerns and food-borne pathogens, Salmonella, Escherichia coli and Campylobacter. FUUAST J Biol, 1(1): 5-17

Aklilu A, Kahase D, Dessalegn M, Tarekegn N, Gebremichael S et al., 2015. Prevalence of intestinal parasites, Salmonella and Shigella among apparently health food handlers of Addis Ababa university student's cafeteria, Addis Ababa, Ethiopia. BMC Res Notes, 8(1): 17, doi: 10.1186/ s13104-014-0967-X

Alizadeh-Sani M, Tavassoli M, Mohammadian E, Ehsani A, Khaniki GJ et al., 2021. pH-responsive color indicator films based on methyl cellulose/ chitosan nanofiber and barberry anthocyanins for real-time monitoring of meat freshness. Int J Biol Macromol, doi: 10.1016/j.ijbiomac.2020.10.231

Assefa A and Bihon A, 2018. A systematic review and meta analysis of prevalence of Escherichia coli in foods of animal origin in Ethiopia. Heliyon, 4(8): e00716, doi: 10.1016/j.heliyon. 2018.e00716

Ayana Z, Yohannis M and Abera Z, 2015. Food-borne bacterial diseases in Ethiopia. Academic J Nutr, 4(1): 62-76, doi: 10.5829/idosi.ajn. 2015.4.1.95168

Badia-Melis R, Mc Carthy U, Ruiz-Garcia L, Hierro JG and Villalba JIR, 2018. New trends in cold chain monitoring applications - A review. Food Control, 86: $170-182$, doi: 10.1016/j.foodcont. 2017.11.022

Bantawa K, Rai K, Limbu SD and Khanal H, 2018. Food-borne bacterial pathogens in marketed raw meat of dharan, Eastern Nepal. BMC Res Notes, 11(1): $1-5$

Bengtsson B and Greko C, 2014. Antibiotic resistanceconsequences for animal health, welfare and food production. Upsala J Med Sci, 119(2): 96-102, doi: 10.3109/03009734.2014.901445

Betsch DF, 1998. In Principles of biotechnology (Webber G, eds). Iowa State University Office of Biotechnology. Available at http:// www.biotech.iastate.edu [9 $9^{\text {th }}$ Sept, 2021]

Bisht A, Kamble MP, Choudhary P, Chaturvedi K, Kohli G et al., 2021. A surveillance of food borne disease outbreaks in India: 2009-2018. Food Control, 121: 170630, doi: 10.1016/ j.foodcont.2020.107630
Boyaci D and Yemenicioğlu A, 2018. Expanding horizons of active packaging: design of consumercontrolled release systems helps risk management of susceptible individuals. Food Hydrocoll, 79: 291-300, doi: 10.1016/j.foodhyd.2017.12.038

BREI, Biotechnology and Research Education Initiative, 2006. Available at http:// www.ca.uky.edu/brei [10th Sept., 2021]

Capita R and Alonso-Calleja C, 2013. Antibioticresistant bacteria: A challenge for the food industry. Crit Rev Food Sci Nutr, 53(1): 11-48, doi: 10.1080/10408398.2010.519837

CD Alert, 2017. Food borne diseases and food safety in India. Monthly Newsletter of the National Centre for Disease Control Directorate General of Health Services, Government of India. Available in https:/ /ncdc.gov.in/WriteReadData/linkimages/ CD\%20Alert4053017156.pdf [10 ${ }^{\text {th }}$ Sept., 2021]

Chen Y, Fu G, Zilberman Y, Ruan W, Ameri SK et al., 2017. Low cost smart phone diagnostics for food using paper-based colorimetric sensor arrays. Food Control, 82(23): 227-232, doi: 10.1016/ j.foodcont.2017.07.003

Chen YW, Cai WQ, Shi YG, Dong XP, Bai F et al., 2020. Effects of different salt concentrations and vacuum packaging on the shelf-stability of Russian sturgeon (Acipenser gueldenstaedti) stored at $4^{\circ} \mathrm{C}$. Food Control, 109: 106865, doi: 10.1016/j.foodcont.2019.106865

Chlebicz A and Slizewska K, 2018. Campylobacteriosis, Salmonellosis, Yersiniosis and Listeriosis as zoonotic food borne diseases: A review. Int J Environ Res Public Health, 15(5): 1-28, doi: 10.3390/ijerph15050863

Chowdhury EU and Morey A, 2019. Intelligent packaging for poultry industry. J Appl Poul Res, 28(4): 791-800, doi: 10.3382/japr/pfz098

da Cunha JA, Heinzmann BM and Baldisserotto B, 2018. The effects of essential oils and their major compounds on fish bacterial pathogens - A review. J Appl Microbiol, 125(2): 328-344, doi: 0.1111/ jam. 13911

de Bruijn I, Liu Y, Wiegertjes GF and Raaijmakers JM, 2018. Exploring fish microbial communities to mitigate emerging diseases in aquaculture. FEMS Microbiol Ecol, 94(1): fix161, doi: 10.1093/ femsec/fix 161

de Freitas AS, de David DB, Takagaki BM, Roesch LFW, 2020. Microbial patterns in rumen are associated with gain of weight in beef cattle. Antonie Van Leeuwenhoek, 113(9): 1299-1312, doi: $10.1007 / \mathrm{s} 10482-020-01440-3$ 
Dhama K, Rajagunalan S, Chakraborty S, Verma AK, Kumar A et al., 2013. Food-borne pathogens of animal origin-diagnosis, prevention, control and their zoonotic signiûcance: A review. Pak J Biol Sci, 16(20): 1076-1085, doi: 10.3923/ pjbs.2013.1076.1085

Dodero A, Escher A, Bertucci S, Castellano M and Lova $\mathrm{P}, 2021$. Intelligent packaging for real-time monitoring of food-quality: current and future developments. Appl Sci, 11(8): 3532, doi: 10.3390/app11083532

Doyle MP and Erickson MC, 2006. Emerging microbiological food safety issues related to meat. Meat Sci, 74(1): 98-112, doi: 10.1016/ j.meatsci.2006.04.009

Duff GC and Galyean ML, 2007. Board-invited review: recent advances in management of highly stressed, newly received feedlot cattle. J Anim Sci, 85(3): 823-840, doi: 10.2527/jas.2006-501

EFSA (European Food Safety Authority), 2007. Introduction of a qualified presumption of safety (QPS) approach for assessment of selected microorganisms referred to EFSA. EFSA J, 5(12): 587, doi: 10.2903/j.efsa.2007.587

Elmonir W, Abo-Remela ME and Sobeih A, 2018. Public health risks of Escherichia coli and Staphylococcus aureus in raw bovine milk sold in informal markets in Egypt. J Infect Dev Ctries, 12(7): 533-541, doi: doi:10.3855/JIDC.9509

Elokil AA, Abouelezz KFM, Ahmad HI, Pan Y and Li S, 2020. Investigation of the impacts of antibiotic exposure on the diversity of the gut microbiota in chicks. Animals, 10(5): 896, doi: 10.3390/ani10050896

Fan B, Qian J, Wu X, Du X, Li W et al., 2019. Improving continuous traceability of food stuff by using barcode-RFID bidirectional transformation equipment: two field experiments. Food Control, 98: 449-456, doi: 10.1016/j.foodcont. 2018.12.002

FAO (Food and Agriculture Organisation), 2010. Options and opportunities in crops, forestry, livestock, fisheries and agro-industry to face the challenges of food insecurity and climate change (ABDC-10). Proceedings of International Technical Conference on Agricultural Biotechnologies in Developing Countries: (Guadalajara, Mexico), pp 1-37

FAO (Food and Animal Organisation), 2019. Livestock and the environment. Retrieved from. http:// www.fao.org/livestock-environment/en/ $\left[10^{\text {th }}\right.$ Sept., 2021]
FDA/FSIS (Food and Drug Administration/Food Safety and Inspection Service), 2003. Quantitative assessment of the relative risk to public health from foodborne Listeria monocytogenes among selected categories of ready-to-eat foods. http:// www.foodsafety.gov/ dms/lmr2 toc.html $\left[10^{\text {th }}\right.$ Sept., 2021]

Felmer R, Chavez R, Catrileo A and Rojas C, 2006. Current and emergent technologies for animal identification and their use in animal traceability. Arch Med Vet, 38(3): 197-206

Ferguson BA, 2017. Look at the microbiology testing market. Food Safety Magazine; Available in https://www.foodsafetymagazine.com/magazinearchive 1/februarymarch-2017/a- look-at-themicrobiology-testing-market/ [10th Sept., 2021]

Fung F, Wang HS and Menon S, 2018. Food Safety in the $21^{\text {st }}$ century. Biomed J, 41(2): 88-95, doi: 10.1016/j.bj.2018.03.003

Graham M, 1994. In Biotechnology in Developing Countries (Edwardson W, Graham M, eds). Ottawa (Canada), pp 7-25

Grandin T, 2006. Progress and challenges in animal handling and slaughter in the US. Appl Anim Behav Sci, 100(1-2): 129-139, doi: 10.1016/ j.applanim.2006.04.016

Grubman MJ and Baxt B, 2004. Foot-and-mouth disease. Clin Microbiol Rev, 17(2): 465-493, doi: 10.1128/CMR.17.2.465-493.2004

Haileselassie M, Taddele H, Adhana K and Kalayou S, 2013. Food safety knowledge and practices of abattoir and butchery shops and the microbial proûle of meat in mekelle city, Ethiopia. Asian Pac J Trop Biomed, 3(5): 407-412, doi: 10.1016/ S2221-1691(13)60085-4

He Y, Yuan QB, Mathieu J, Stadler L, Senehi N et al., 2020. Antibiotic resistance genes from livestock waste: Occurrence, dissemination and treatment. NPJ Clean Water, 3(1): 1-11, doi: 10.1038/ s41545-020-0051-0

Hemalata VB and Virupakshaiah DBM, 2016. Isolation and identification of food borne pathogens from spoiled food samples. Int J Curr Microbiol Appl Sci, 5(6): 1017-1025, doi: 10.20546/ ijcmas.2016.506.108

Heredia N and Garcia S, 2018. Animals as sources of food-borne pathogens: A review. Anim Nutr, 4(3): 250-255, doi: 10.1016/j.aninu.2018.04.006

Hogeveen H, Huijps K and Lam TJ, 2011. Economic aspects of mastitis: new developments. NZ Vet J, 59(1):16-23, doi: 10.1080/00480169.2011. 547165 
Huws SA, Creevey CJ, Oyama LB, Mizrahi I, Denman SE et al., 2018. Addressing global ruminant agricultural challenges through understanding the rumen microbiome: past, present, and future. Front Microbiol, 9: 2161, doi: 10.3389/fmicb. 2018.02161

ICMSF (International Commission on Microbiological Speciûcations for Foods), 2002. Microorganisms in foods 7- microbial testing in food safety management. Kluwer Academic/Plenum Publishers, New York, NY, pp 362

IDSP (Integrated Disease Surveillance Programme), 2019. Diseases under surveillance. In: About IDSP

ILSI (International Life Sciences Institute) Research Foundation/Risk Science Institute, 2005. Achieving continuous improvement in reductions in foodborne listeriosis - A risk-based approach. J Food Prot, 68(9): 1932-1994, doi: 10.4315/0362028x-68.9.1932

Jaiswal RK, Mendiratta SK, Talukder S, Soni A, Chand S et al., 2020. Application of lipase based enzymatic time temperature indicator (TTI) as quality marker for frozen chicken meat. Food Sci Technol Res, 26(1): 9-16, doi: 10.3136/fstr.26.9

Jia R, Tian W, Bai H, Zhang J, Wang S et al., 2019. Amine-responsive cellulose-based ratiometric fluorescent materials for real-time and visual detection of shrimp and crab freshness. Nat Commun, 10(1): 795, doi: 10.1038/s41467-01908675-3

Jin L, Li T, Wu B, Yang T, Zou D et al., 2020. Rapid detection of Salmonella in milk by nuclear magnetic resonance based on membrane filtration super paramagnetic nano biosensor. Food Control, 110: 107011, doi: 10.1016/j.foodcont. 2019.107011

Joyce A, McCarthy CGP, Murphy S and Walsh F, 2019. Antibiotic resistomes of healthy pig faecal metagenomes. Microb Genom, 5(5): e000272, doi: 10.1099/mgen.0.000272

Kadariya J, Smith CT and Thapaliya D, 2014. Staphylococcus aureus and Staphylococcal foodborne disease: An ongoing challenge in public health. BioMed Res Int, 2014: 827965, doi: $10.1155 / 2014 / 827965$

Kearney J, 2010. Food consumption trends and drivers. Philos Trans R Soc B Biol Sci, 365(1554): 27932807, doi: 10.1098/rstb.2010.0149

King T, Cole M, Farber JM, Eisenbrand G, Zabaras D et al., 2017. Food safety for food security: relationship between global megatrends and developments in food safety. Trends Food Sci Technol, 68: 160-175, doi: 10.1016/j.tifs.2017.08.014
Koutsoumanis KP, Geornaras I and Sofos JN, 2006. Microbiology of land animals. In: Handbook of Food Science, Technology and Engineering (Hui YH, eds). Boca Raton, FL: CRC Press Taylor \& Francis Group, Vol. 1, 15-744-45510, Chapter 52.1, pp 52.1-52.43

Kuebutornye FKA, Wang Z, Lu Y, Abarike ED, Sakyi ME et al., 2020. Effects of three host-associated Bacillus species on mucosal immunity and gut health of Nile tilapia, Oreochromis niloticus and its resistance against Aeromonas hydrophila infection. Fish Shellfish Immunol, 97: 83-95, doi: 10.1016/j.fsi.2019.12.046

Kumar S, Mukherjee A and Dutta J, 2020. Chitosan based nanocomposite films and coatings: emerging antimicrobial food packaging alternatives. Trends Food Sci Technol, 97: 196209, doi: 10.1016/j.tifs.2020.01.002

Lee SB, Kim DH, Jung SW and Lee SJ, 2019. Airactivation of printed time-temperature integrator: A sandwich package case study. Food Control, 101: 89-96, doi: 10.1016/j.foodcont.2019.02.021

Lee SY, Lee SJ, Choi DS and Hur SJ, 2015. Current topics in active and intelligent food packaging for preservation of fresh foods. J Sci Food Agric, 95(14): 2799-2810, doi: 10.1002/jsfa.7218

Lin L, Dai Y and Cui H, 2017. Antibacterial poly (ethylene oxide) electrospun nanofibers containing cinnamon essential oil/beta cyclodextrin proteoliposomes. Carbohydr Polym, 178: 131-140, doi: 10.1016/j.carbpol.2017.09.043

Liu J, Jasim I, Shen Z, Zhao L, Dweik Metal., 2019. A microfluidic based biosensor for rapid detection of Salmonella in food products. Plos One, 14(5): e0216873, doi: 10.1371/journal.pone.0216873

Lopez-Gomez A, Cerdan-Cartagena F, SuardiazMuro J, Boluda-Aguilar M, Hernandez-Hernandez ME et al., 2014. Radio frequency identification and surface acoustic wave technologies for developing the food intelligent packaging concept. Food Eng Rev, 7(1): 11-32, doi: 10.1007/ s12393-014-9102-y

Maltecca C, Bergamaschi M and Tiezzi F, 2020. The interaction between microbiome and pig eficiency: A review. J Anim Breed Genet, 137(1): 4-13, doi: 10.1111/jbg.12443

Mc Dermott PF, Zhao S, Wagner DD, Simjee S, Walker RD et al., 2002. The food safety perspectice of antibiotic resistance. Anim Biotechnol, 13(1): 7184, doi: 10.1081/ABIO-120005771

McMeekin TA, Brown J, Krist K, Miles D, Neumeyer K et al., 1997. Quantitative microbiology: A basis 
for food safety. Emerg Infect Diseas, 3(4): 541-549, doi: 10.3201/eid0304.970419

Mijanur Rahman ATM, Kim DH, Jang HD, Yang JH and Lee SJ, 2018. Preliminary study on biosensortype time-temperature integrator for intelligent food packaging. Sensors (Basel), 18(6): 1949, doi: 10.3390/s18061949

Mohammadalinejhad S, Almasi H and Moradi M, 2020. Immobilization of Echium amoenum anthocyanins into bacterial cellulose film: A novel colorimetric $\mathrm{pH}$ indicator for freshness/spoilage monitoring of shrimp. Food Control, 113: 107169, doi: 10.1016/j.foodcont.2020.107169

Mohammadian E, Alizadeh-Sani M and Jafari SM, 2020. Smart monitoring of gas/temperature changes within food packaging based on natural colorants. Compr Rev Food Sci Food Saf, 19(6): 2885-2931, doi: 10.1111/1541-4337.12635

Mottet A, de Haan C, Falcucci A, Tempio G, Opio C et al., 2017. Livestock: on our plates or eating at our table? A new analysis of the feed/food debate. Glob Food Secur, 14: 1-8, doi: 10.1016/ j.gfs.2017.01.001

Muller P and Schmid M, 2019. Intelligent packaging in the food sector: A brief overview. Foods, 8(1): 16, doi: 10.3390/foods 8010016

Mustafa F and Andreescu S, 2018. Chemical and biological sensors for food-quality monitoring and smart packaging. Foods, 7(10): 168, doi: 10.3390/ foods 7100168

Navas-Carretero S, Pérez-Granados A, Sarria B, Carbajal A, Pedrosa M et al., 2008. Oily fish increases iron bioavailability of a phytate rich meal in young iron deûcient women. J Am Coll Nutr, 27(1): 96-101, doi: 10.1080/ 07315724.2008.10719680

Naveena BM, Jagadeesh DS, Jagadeesh Babu A, Madhava Rao T, Kamuni V et al., 2017. OFFGEL electrophoresis and tandem mass spectrometry approach compared with DNA-based PCR method for authentication of meat species from raw and cooked ground meat mixtures containing cattle meat, water buffalo meat and sheep meat. Food Chem, 233: 311-320, doi: 10.1016/ j.foodchem.2017.04.116

Ochoa ML and Harrington PB, 2005. Immunomagnetic isolation of enterohemorrhagic Escherichia coli O157: H7 from ground beef and identification by Matrix-Assisted Laser Desorption/Ionization Time-of-Flight Mass Spectrometry and database searches. Anal Chem, 77(16): 5258-5267, doi: 10.1021/ac0502596
Oh TG, Lee JH, Koo YK, Cha HJ, Woo SY et al., 2021. Control of temperature dependence of microbial time-temperature integrator (TTI) by microencapsulation of lactic acid bacteria into micro beads with different proportions of alginate. Food Sci Biotechnol, 30(4): 571-582, doi: 10.1007/s10068-021-00884-1

Okechukwu QN, Javed F and Ivantsova MN, 2019. Advancement of food processing biotechnology in developing countries. In: Proceedings of the AIP Conference, 2174(1): 020236, doi: org/ 10.1063/1.5134387

Okocha RC, Olatoye IO and Adedeji OB, 2018. Food safety impacts of antimicrobial use and their residues in aquaculture. Public Health Rev, 39:21, doi: 10.1186/s40985-018-0099-2

Olatunde OO and Benjakul S, 2018. Non thermal processes for shelf-life extension of sea foods: A revisit. Compr Rev Food Sci Food Saf, 17(4): 892904, doi: 10.1111/1541-4337.12354

Oliva-Teles A, 2012. Nutrition and health of aquaculture ûsh. J Fish Dis, 35(2): 83-108, doi: 10.1111/j.1365-2761.2011.01333.x

Oliver SP, Jayarao BM and Almeida RA, 2005. Food borne pathogens in milk and the dairy farm environment: food safety and public health implications. Foodborne Pathog Dis, 2(2): 115129, doi: 10.1089/fpd.2005.2.115

Page SW and Gautier P, 2012. Use of antimicrobial agents in livestock. Rev Sci Tech, 31(1): 145-188, doi: 10.20506/rst.31.1.2106

Pal M, Patel AS, Bariya AS, Godishala V and Ramana $\mathrm{KV}$, 2017. A review of biotechnological applications in food processing of animal origin. Am J Food Sci Technol, 5(4): 143-148, doi: 10.12691/ajfst-5-4-4

Pandian AT, Chaturvedi S and Chakraborty S, 2020. Applications of enzymatic time-temperature indicator (TTI) devices in quality monitoring and shelf-life estimation of food products during storage. J Food Meas Charact, 15(2): 1523-1540, doi: 10.1007/s11694-020-00730-8

Peixoto RS, Harkins DH and Nelson KE, 2021. Advances in microbiome research for animal health. Annu Rev Anim Biosci, 9: 289-311, doi: 10.1146/annurev-animal-091020-075907

Preena PG, Swaminathan TR, Kumar VJR and Singh ISB, 2020. Antimicrobial resistance in aquaculture: A crisis for concern. Biologia, 75: 1497-1517, doi: 10.2478/s11756-020-00456-4

Quan J, Wu Z, Ye Y, Peng L, Wu J et al., 2020. Metagenomic characterization of intestinal 
regions in pigs with contrasting feed eficiency. Front Microbiol, 11: 32, doi: 10.3389/ fmicb.2020.00032

Ranganathan J, Vennard D, Waite R, Dumas P, Lipinski B et al., 2016. Shifting Diets for a Sustainable Food Future. Report No. 1, World Resources Institute, Washington DC, US, pp 90, doi: 10.13140/ RG.2.1.3808.2961

Ringo E, Hoseinifar SH, Ghosh K, Van Doan H, Becks BR et al., 2018. Lactic acid bacteria in finfish- An update. Front Microbiol, 9: 1818, doi: 10.3389/ fmicb.2018.01818

Schwarz S, Cavaco L and Shen J, 2018. Antimicrobial resistance in bacteria from livestock and companion animals. American Society of Microbiology Press, Washington, USA

Sheng L and Wang L, 2020. The microbial safety of fish and fish products: Recent advances in understanding its significance, contamination sources, and control strategies. Compr Rev Food Sci Food Saf, 20(1): 738-786, doi: 10.1111/15414337.12671

Shimohata T, Hirota K, Takahashi $\mathrm{H}$ and Nishizawa M, 2015. Clinical aspects of Niigata Minamata disease. Brain Nerve, 67(1): 31-38, doi: 10.11477/ mf.1416200084

Smith J, 2017. The role of livestock in development countries: mis-perceptions, facts and consequences. In: Presentation at the Workshop on Extinction and Livestock: Moving to a Flourishing Food System for Wildlife, Farm Animals, and Us, London, UK, March 6-7, Available at https://www.slideshare.net/ILRI/ extinction-livestock-smithoct17 [10th Sept., 2021]

Sofos JN and Smith GC, 1998. Nonacid meat decontamination technologies: model studies and commercial applications. Int J Food Microbiol, 44(3): 171-188, doi: 10.1016/s01681605(98)00136-6

Sofos JN, 2005. Improving the Safety of Fresh Meat. Cambridge, UK: CRC/Woodhead Publishing Limited, pp 780

Sofos JN, 2008. Challenges to meat safety in the $21^{\text {st }}$ century. Meat Sci, 78(1-2): 3-13, doi: 10.1016/ j.meatsci.2007.07.027

Soltani Firouz M, Mohi-Alden K and Omid M, 2021. A critical review on intelligent and active packaging in the food industry: research and development. Food Res Int, 141: 110113, doi: 10.1016/j.foodres.2021.110113

Sørensen JS, Boknæs N, Mejlholm O and Dalgaard P, 2020. Superchilling in combination with modified atmosphere packaging resulted in long shelf-life and limited microbial growth in Atlantic cod (Gadus morhua L.) from capture-basedaquaculture in Greenland. Food Microbiol, 88: 103405, doi: 10.1016/j.fm.2019.103405

Stabler SP and Allen RH, 2004. Vitamin B12 deficiency as a worldwide problem. Annu. Rev. Nutr, 24: 299326, doi:10.1146/annurev.nutr.24.012003. 132440

Sternisa M, Mraz J and Mozina SS, 2016. Microbiological aspects of common carp (Cyprinus carpio) and its processing-relevance for final product quality: A review. Aquacult Int, 24(6):1569-1590, doi: 10.1007/s10499-0160051-8

Sun HZ, Zhou M, Wang O, Chen Y, Liu JX et al., 2020. Multi-omics reveals functional genomic and metabolic mechanisms of milk production and quality in dairy cows. Bioinformatics, 36(8): 25302537, doi: 10.1093/bioinformatics/btz951

Swartz NM, 2002. Human diseases caused by foodborne pathogens of animal origin. Clin Infect Dis, 34(Supp 3): 111-122, doi: 10.1086/340248

Swayne DE, 2006. Microassay for measuring thermal inactivation of $\mathrm{H} 5 \mathrm{~N} 1$ high pathogenicity avian influenza virus in naturally infected chicken meat. Int J Food Microbiol, 108: 268-271, doi: 10.1016/ j.ijfoodmicro.2005.08.032

Talwar C, Nagar S, Lal R and Negi RK, 2018. Fish gut microbiome: current approaches and future perspectives. Indian J Microbiol, 58(4): 397-414, doi: $10.1007 / \mathrm{s} 12088-018-0760-y$

Thomas JK and Noppenberger J, 2007. Avian infiuenza: A review. Am J Health-Syst Pharm, 64(2): 149-165, doi: 10.2146/ajhp060181

Tompkin RB, 2002. Control of Listeria monocytogenes in the food-processing environment. J Food Prot, 65(4): 709-725, doi: 10.4315/0362-028x65.4.709

Tsepo R, Ngoma L, Mwanza M and Ndou R, 2016. Prevalence and antibiotic resistance of Staphylococcus aureus isolated from beef carcasses at abattoirs in north west province, J Hum Ecol, 56: 188-195, doi: 10.1080/ 09709274.2016.11907055

USHHS and USDA (US Department of Health and Human Services and US Department of Agriculture), 2015. 2015-2020 Dietary Guidelines for Americans, 8th edn.

Vaarten J, 2012. Clinical impact of antimicrobial resistance in animals. Rev Sci Tech, 31(1): 221229, doi: 10.20506/rst.31.1.2110 
Van Boeckel TP, Brower C, Gilbert M, Grenfell BT, Levin SA et al., 2015. Global trends in antimicrobial use in food animals. Proc Natl Acad Sci, 112(18): 5649-5654, doi: 10.1073/ pnas. 1503141112

Wang C, Li P, Yan Q, Chen L, Li T et al., 2019c. Characterization of the pig gut microbiome and antibiotic resistome in industrialized feedlots in China. mSystems, 4(6): e00206-e00219, doi: 10.1128/mSystems.00206-19

Wang L, Wu Z and Cao C, 2019d. Technologies and fabrication of intelligent packaging for perishable products. App Sci, 9(22): 4858, doi: 10.3390/ app9224858

Wang W, Hu H, Zijlstra RT, Zheng J and Gänzle MG, 2019b. Metagenomic reconstructions of gut microbial metabolism in weanling pigs. Microbiome, 7: 48

Wang W, Sadeqi A, Nejad HR and Sonkusale S, 2020. Cost-effective wireless sensors for detection of package opening and tampering. IEEE Access, 8: 117122-117132, doi: 10.1109/access.2020. 3004438

Wang X, Tsai T, Deng F, Wei X, Chai J et al., 2019a. Longitudinal investigation of the swine gut microbiome from birth to market reveals stage and growth performance associated bacteria. Microbiome, 7: 109, doi: 10.1186/s40168-0190721-7

Weston M, Phan MAT, Arcot J and Chandrawati R, 2020. Anthocyanin-based sensors derived from food waste as an active use-by date indicator for milk. Food Chem, 326: 127017, doi: 10.1016/ j.foodchem.2020.127017

Whitley RJ and Monto AS, 2006. Seasonal and pandemic influenza preparedness: A global threat. J Infect Dis, 194(Suppl 2): 565-569, doi: 10.1086/ 507562

WHO (World Health Organization), 2014. World health assembly global nutrition targets 2025: stunting policy brief. Available in http://www.who.int/ nutrition/topics/ globaltargets_stunting_ policy brief.pdf [10 ${ }^{\text {th }}$ Sept., 2021]

WHO (World Health Organization), 2015. WHO estimates of the global burden of foodborne diseases- Foodborne diseases burden epidemiology reference group 2007-2015. Available in http://www.who.int/foodsafety/ publications/ foodborne_disease/fergreport/en/ [10 ${ }^{\text {th }}$ Sept., 2021]
Yang P, Hash S, Park K, Wong C, Doraisamy L et al., 2017. Application of nuclear magnetic resonance to detect toxigenic Clostridium difficile from stool specimens: A proof of concept. J Mol Diagn, 19(2): 230-235, doi: 10.1016/j.jmoldx.2016.09.012

Yang P, Wong C, Hash S, Fung F and Menon S, 2018. Rapid detection of Salmonella spp using magnetic resonance. J Food Saf, 12473, doi: 10.1111/jfs. 12473

Ye Y, Guo H and Sun X, 2019. Recent progress on cellbased biosensors for analysis of food safety and quality control. Biosens Bioelectron, 126: 389404, doi: 10.1016/j.bios.2018.10.039

Yeh H, Skubel SA, Patel H, Shi DC, Bushek D et al., 2020. From farm to fingers: An exploration of probiotics for oysters, from production to human consumption. Probiotics Antimicrob Proteins, 12(2): 351-364, doi: 10.1007/s12602-01909629-3

Yousefi H, Su HM, Imani SM, Alkhaldi K, Filipe CDM et al., 2019. Intelligent food packaging: A review of smart sensing technologies for monitoring food quality. ACS Sens, 4(4): 808-821, doi: 10.1021/ acssensors.9b00440

Zhai X, Li Z, Shi J, Huang X, Sun Z et al., 2019. A colorimetric hydrogen sulfide sensor based on gellan gum-silver nanoparticles bionanocomposite for monitoring of meat spoilage in intelligent packaging. Food Chem, 290: 135-143, doi: 10.1016/j.foodchem.2019. 03.138

Zhang J, Wang D, Eldridge A, Huang F, Ouyang Y et al., 2017. Urban-rural disparities in energy intake and contribution of fat and animal source foods in Chinese children aged 4-17 years. Nutrients, 9(5): 526, doi: 10.3390/nu9050526

Zhang X, Guo M, Ismail BB, He Q, Jin TZ et al., 2021. Informative and corrective responsive packaging: advances in farm-to-fork monitoring and remediation of food quality and safety. Compr Rev Food Sci Food Safe, 20(5): 5258-5282, doi: $10.1111 / 1541-4337.12807$

Zhang X, Wu D, Zhou X, Yu Y, Liu J et al., 2019. Recent progress in the construction of nanozyme based biosensors and their applications to food safety assay. TrAC Trends Anal Chem, 121: 115668, doi: 10.1016/j.trac.2019.115668

Zhao X, Lin C, Wang J and Oh D, 2014. Advances in rapid detection methods for foodborne pathogens. J Microbiol Biotechnol, 24(3): 297-312, doi: 10.4014/jmb.1310.10013

Received - 15.09.2021, Accepted - 02.11.2021, Published-01.12.2021

Section Editors: Prof. S. Biswas and Dr. A. K. Das, Members, Editorial Board 